UDC 693.546

\title{
IMPACT OF CRANKS DISPLACEMENT ANGLE ON THE MOTION NON-UNIFORMITY OF ROLLER FORMING UNIT WITH ENERGY-BALANCED DRIVE
}

\author{
V. S. Loveikin ${ }^{1}$, \\ Doctor of Technical Science, Professor \\ K. I. Pochka ${ }^{2}$, \\ Doctor of Technical Science, Associate Professor \\ M. O. Prystailo ${ }^{2}$, \\ Candidate of Science (Engineering), Associate Professor \\ M. M. Balaka ${ }^{2}$, \\ Candidate of Science (Engineering) \\ O. B. Pochka ${ }^{2}$ \\ ${ }^{1}$ National University of Life and Environmental Sciences of Ukraine \\ 15, Heroiv Oborony St., Kyiv, Ukraine, 03041 \\ ${ }^{2}$ Kyiv National University of Construction and Architecture \\ 31, Povitroflotsky Ave., Kyiv, Ukraine, 03037
}

DOI: $10.32347 / 2410-2547.2021 .106 .141-155$

The impact of cranks displacement angle on the motion non-uniformity is determined for a roller forming unit with an energy-balanced drive mechanism. At the same time, the roller forming unit is presented by a dynamic model with one freedom degree, for which the differential equation of motion is write down. As a result of solving the differential equation, it has been obtained that the change function of the crank angular velocity from start-up moment and during steady motion mode. After that, we calculated the time corresponding to the angular velocity value, and obtained the change function of the crank angular acceleration from start-up moment and during steady motion mode. The motion non-uniformity of the roller forming unit has been determined by the motion non-uniformity factor, the motion dynamism factor and the extended factor of motion assessment during steady motion mode. The impact of drive cranks displacement angle on the motion non-uniformity has been traced, as a result, the specified factors have the minimum values at cranks displacement on the angle $\Delta \varphi=60^{\circ}$.

Keywords: roller forming unit, drive mechanism, displacement, angular velocity, acceleration, non-uniformity.

\section{Introduction}

In the existing units for surface compacting of products from building mixtures the slider-crank or hydraulic drive at reciprocating motion of the forming trolley with the compaction rollers is used [1-4]. During continuous start-stop modes, considerable dynamic loads appear both in the drive mechanism and forming trolley elements, which may lead to the premature failure of the unit.

\section{Analysis of publications}

In the existing theoretical and experimental studies of roller forming units designed for forming products from building mixtures, their design parameters

(C) Loveikin V. S., Pochka K. I., Prystailo M. O., Balaka M. M., Pochka O. B. 
and productivity are substantiated [1-4]. At the same time, insufficient attention is paid to the study of the existing dynamic loads [5-14] and motion modes $[15,16]$, which greatly impact both the operation of the unit and the quality of the finished products. Therefore, the task of studying the motion non-uniformity of roller forming units is actual. In [16], the motion nonuniformity of a roller forming unit with an energy-balanced drive mechanism for three forming trolleys was investigated, however, the impact of cranks displacement angle on the motion non-uniformity was not taken into account.

\section{Purpose of the paper}

The purpose of this paper is to research the impact of cranks displacement angle on the motion non-uniformity of the roller forming unit with energybalanced drive mechanism.

\section{Research results}

In order to reduce energy consumption in roller forming machines, a design of the roller forming unit $[17,18]$ was proposed to provide the compaction of products from building mixtures on a single technological line. It consists of three forming trolleys, located parallel to each other on one side of the drive shaft, which are set in reciprocating motion from the one drive. It is composed of three slider-crank mechanisms, whose cranks are rigidly fixed on one drive shaft and shifted to each other at the angle $\Delta \varphi=120^{\circ}$ (Fig. 1 (a)). Each of the forming trolleys 1,2 and 3 is mounted on the gantry 11 and performs reciprocating motion in the guide rails 12 over the cavity of the form 13 . The forming trolley 1 consists of the feeding hopper 14 and coaxial sections of the compaction rollers 15. The other two trolleys have the same design. The trolleys 1,2 and 3 with distributive hoppers are set into reciprocating motion by a drive made in the form of three slider-crank mechanisms, whose cranks 7, 8 and 9 are rigidly fixed on one drive shaft 10 and shifted to each other at the angle $\Delta \varphi=120^{\circ}$. The connecting rods 4,5 and 6 are hinged to the forming trolleys 1,2 and 3, while their other ends are connected to the cranks 7, 8 and 9. Such a design of the roller forming unit makes it possible to reduce the dynamic loads in the drive elements, extra devastating loads on the frame structure and, accordingly, to increase the unit durability as a whole. Fig. 1, b shows a kinematic scheme of the roller forming unit with energy-balanced drive for compacting reinforced concrete products on a single technological line.

In such units there is a certain motion non-uniformity of the forming trolleys during the compaction process of the building mixture, leading to reduce of product quality and arise of significant dynamic loads on the drive and unit structural elements.

The motion non-uniformity in the first approximation can be determined for the roller forming unit by the presented dynamic model with one freedom degree, where the extended coordinate is taken as the angular coordinate of the crank rotation.

For this model, we wrote down the differential equation of motion 


$$
J_{d r}(\varphi) \cdot \omega \cdot \frac{d \omega}{d \varphi}+\frac{\omega^{2}}{2} \cdot \frac{d J_{d r}(\varphi)}{d \varphi}=M_{d r}(\omega)-M_{r e s}(\varphi),
$$

where $\varphi, \omega$ - angular coordinate and the crank speed; $J_{d r}(\varphi)$ - inertia moment, reduced to the crank rotation axis; $M_{d r}(\omega)$ - driving moment on the driving electric motor shaft, reduced to the crank rotation axis; $M_{\text {res }}(\varphi)-$ moment of all acting external forces, reduced to the crank rotation axis, taken into account the resistance force to the shift of the forming trolleys and the gravity force of the connecting rods.

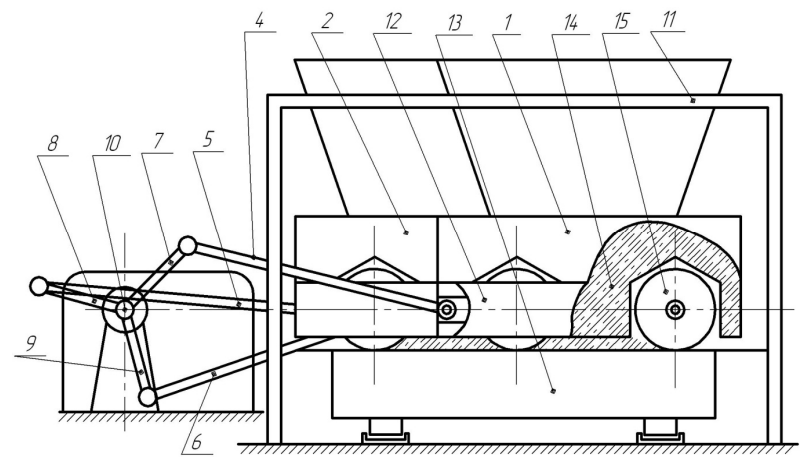

(a)

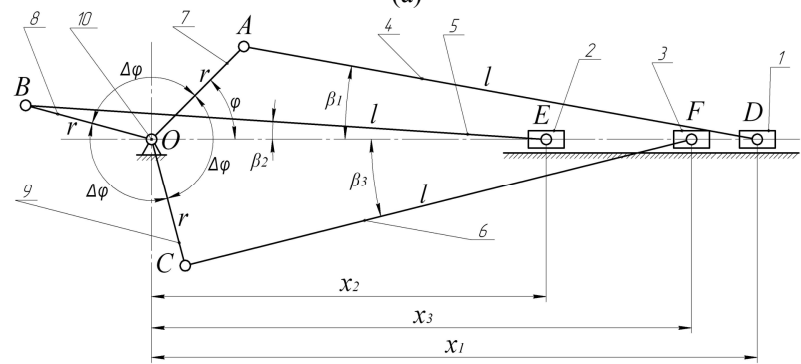

(b)

Fig. 1. Roller forming unit with an energy-balanced drive (a) and its kinematic scheme (b)

The equation (1) is a nonlinear first-order equation that cannot be analytically integrated. Therefore, the numerical method proposed by Professor Baranov was used to solve it [19]. According to this method, the equation (1) will have the look

$$
2 J_{d r}(\varphi) \cdot d \omega+\omega \cdot d J_{d r}(\varphi)=2 \frac{M_{d r}(\omega)-M_{r e s}(\varphi)}{\omega} \cdot d \varphi .
$$

Having replaced in the equation (2): $d \varphi \approx \Delta \varphi$ - integration step; $d J_{d r} \approx J_{d r(i+1)}-J_{d r(i)} ; d \omega=\omega_{i+1}-\omega_{i} ; \Delta \varphi=\varphi_{i+1}-\varphi_{i} ;$ we obtain

$$
2 \cdot J_{d r(i)} \cdot\left(\omega_{i+1}-\omega_{i}\right)+\omega_{i} \cdot\left(J_{d r(i+1)}-J_{d r(i)}\right)=2 \cdot \frac{M_{d r}\left(\omega_{i}\right)-M_{r e s}\left(\varphi_{i}\right)}{\omega_{i}},
$$


where $\varphi_{i}, \omega_{i}, J_{d r(i)}, M_{d r}\left(\omega_{i}\right), M_{r e s}\left(\varphi_{i}\right)$ - accordingly angular coordinate of the crank, angular velocity of the crank, inertia moment, driving moment and resistance forces moment, reduced to the crank rotation axis in position $i$ $(i=0,1,2, \ldots, n) ; n$ - number of settlement points; $\varphi_{i+1}, \omega_{i+1}, J_{d r(i+1)}-$ accordingly angular coordinate, speed and inertia moment of the mechanism, reduced to the crank rotation axis in position $i+1$.

Having solved equation (3) with respect to $\omega_{i+1}$, we obtain

$$
\omega_{i+1}=\frac{\left[M_{d r}\left(\omega_{i}\right)-M_{r e s}\left(\varphi_{i}\right)\right]}{J_{d r(i)} \cdot \omega_{i}} \Delta \varphi+\frac{\left(3 J_{d r(i)}-J_{d r(i+1)}\right)}{2 J_{d r(i)}} \omega_{i} .
$$

To solve equation (4), all necessary characteristics of the roller forming unit were found.

The resistance forces moment, reduced to the crank rotation axis, $M_{\text {res }}=M_{\text {res }}(\varphi)$ is determined by the dependence

$$
M_{\text {res }}=F_{0} \cdot \frac{\partial x_{1}}{\partial \varphi}+F_{0} \cdot \frac{\partial x_{2}}{\partial \varphi}+F_{0} \cdot \frac{\partial x_{3}}{\partial \varphi}+G_{4} \cdot \frac{\partial y_{s 4}}{\partial \varphi}+G_{5} \cdot \frac{\partial y_{s 5}}{\partial \varphi}+G_{6} \cdot \frac{\partial y_{s 6}}{\partial \varphi},
$$

where $\frac{\partial x_{1}}{\partial \varphi}, \frac{\partial x_{2}}{\partial \varphi}, \frac{\partial x_{3}}{\partial \varphi}, \frac{\partial y_{s 4}}{\partial \varphi}, \frac{\partial y_{s 5}}{\partial \varphi}, \frac{\partial y_{s 6}}{\partial \varphi}$ - first transfer functions of the trolleys masses centers 1,2 and 3 , and the vertical components for first transfer functions of the connecting rods masses centers 4, 5 and 6 (Fig. 1), which are defined as follows

$$
\begin{gathered}
\frac{\partial x_{1}}{\partial \varphi}=-r \cdot \sin \varphi \cdot\left(1+\frac{r}{l} \cdot \frac{\cos \varphi}{\sqrt{1-\left(r^{2} / l^{2}\right) \cdot \sin ^{2} \varphi}}\right) \\
\frac{\partial x_{2}}{\partial \varphi}=-r \cdot \sin (\varphi+\Delta \varphi)\left(1+\frac{r}{l} \frac{\cos (\varphi+\Delta \varphi)}{\sqrt{1-\left(r^{2} / l^{2}\right) \cdot \sin ^{2}(\varphi+\Delta \varphi)}}\right), \\
\frac{\partial x_{3}}{\partial \varphi}=-r \sin (\varphi+2 \Delta \varphi)\left(1+\frac{r}{l} \frac{\cos (\varphi+2 \Delta \varphi)}{\sqrt{1-\left(r^{2} / l^{2}\right) \cdot \sin ^{2}(\varphi+2 \Delta \varphi)}}\right), \\
\frac{\partial y_{s 4}}{\partial \varphi}=\frac{r}{2} \cdot \cos \varphi, \quad \frac{\partial y_{s 5}}{\partial \varphi}=\frac{r}{2} \cdot \cos (\varphi+\Delta \varphi), \quad \frac{\partial y_{s 6}}{\partial \varphi}=\frac{r}{2} \cdot \cos (\varphi+2 \Delta \varphi) .
\end{gathered}
$$

Here $r$ - crank radius; $l$ - length of connecting rods; $F_{0}$ - resistance force to the shift of the forming trolley, which is determined by the method described in [4]; $G_{4}=G_{5}=G_{6}=l \cdot q \cdot g$ - gravity of connecting rods 4,5 and $6 ; q$ - length mass of the connecting rod; $g=9,81 \mathrm{~m} / \mathrm{s}^{2}-$ free fall acceleration; $\Delta \varphi$ - crank displacement angle.

For the roller forming unit with the parameters $(r=0,2 \mathrm{~m}, l=0,8 \mathrm{~m}$, $q=80 \mathrm{~kg} / \mathrm{m})$ the resistance force [4] $F_{0}=3562 \mathrm{~N}$, that required to move the 
forming trolley with two $R=0,11 \mathrm{~m}$ compaction rollers, was determined for the formation of products with the following characteristics: product height $h_{0}=0,22 \mathrm{~m}$, product width $B=1,164 \mathrm{~m}$; compacted mixture type - finegrained mixture; concrete mixture humidity $W=10 \%$; required product compactness $k_{\text {comp }}=0,98$; value of the maximum contact pressure providing $k_{\text {comp }}=0,98$ at $W=10 \%$, according to experimental data $p=625 \mathrm{kPa}$.

All external forces were reduced to the crank rotation axis and are presented as the resistance forces moment to move the forming trolley depending on the crank rotation angle (Fig. 2, a). The mean value of the resistance forces moment for one crank rotation cycle is determined

$$
M_{\text {resmean }}=\frac{1}{2 \pi} \cdot \int_{0}^{2 \pi} M_{r e s}(\varphi) \cdot d \varphi=1360,55 \mathrm{~N} \cdot \mathrm{m}
$$

and the nominal rated power of the electric motor is determined

$$
P_{\text {nom }}=\frac{M_{\text {resmean }} \cdot \omega_{1}}{10^{3} \cdot \eta}=\frac{1360,55 \cdot 10,5}{10^{3} \cdot 0,95}=15,04 \mathrm{~kW},
$$

where $\omega_{1}=10,5 \mathrm{rad} / \mathrm{s}$ - crank angular velocity; $\eta=0,95$ - drive efficiency.

According to these data, a 4A series 4A160M6U3 basic-version asynchronous electric motor with a short-circuited rotor was chosen [20], having the parameters: electric motor power $P=15,0 \mathrm{~kW}$; engine rotor synchronous speed $\omega_{o}=104,72 \mathrm{rad} / \mathrm{s}$; engine rotor nominal speed $\omega_{\text {nom }}=102,1 \mathrm{rad} / \mathrm{s}$; engine rotor critical speed $\omega_{\text {crit }}=94,95 \mathrm{rad} / \mathrm{s}$; engine rotor inertia moment $J_{e m}=0,183 \mathrm{~kg} \cdot \mathrm{m}^{2} ;$ start-up moment $M_{\text {start }}=176,3 \mathrm{~N} \cdot \mathrm{m}$; nominal moment $M_{n o m}=146,9 \mathrm{~N} \cdot \mathrm{m}$; critical moment $M_{\text {crit }}=293,8 \mathrm{~N} \cdot \mathrm{m}$; overload capacity $\lambda=M_{\text {crit }} / M_{\text {nom }}=2$. In addition, the pin flexible coupling [21] having the nominal transfer moment $M_{\text {nom }}=500 \mathrm{~N} \cdot \mathrm{m}$ and inertia moment $J_{c t h}=0,32 \mathrm{~kg} \cdot \mathrm{m}^{2}$ as well as the $\mathrm{C} 2-400$ reducer with the transmission ratio $i_{d r}=9,8$ and inertia moment $J_{\text {red }}=0,036 \mathrm{~kg} \cdot \mathrm{m}^{2}$ were selected.

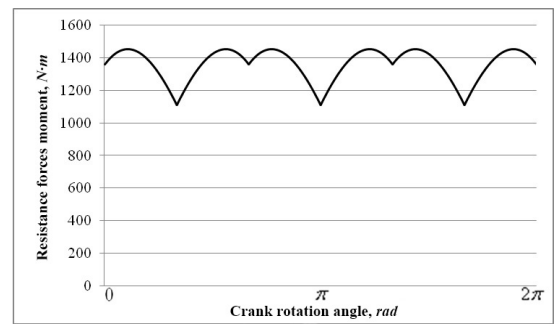

(a)

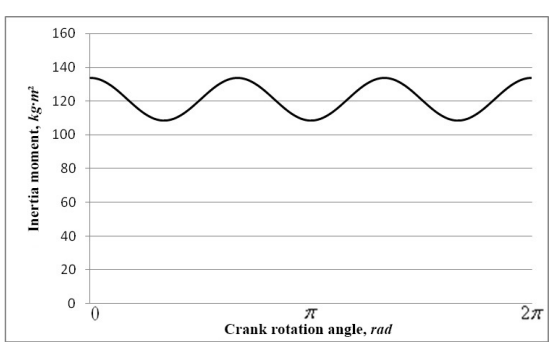

(b)

Fig. 2. Graphic dependencies of the resistance forces moment to move of forming trolleys (a) and the inertia moment (b) on the crank rotation angle of unit with energy-balanced drive 
The mechanical characteristic for the selected electric motor is constructed, which is determined by the Kloss formula

$$
M(\omega)=2 \cdot M_{\text {crit }} \cdot \frac{\left(\omega_{o}-\omega\right) /\left(\omega_{o}-\omega_{\text {crit }}\right)}{1+\left[\left(\omega_{o}-\omega\right) /\left(\omega_{o}-\omega_{\text {crit }}\right)\right]^{2}} .
$$

From the dependence (7) we determinate the driving moment on the crankshaft

$$
M_{d r}=M(\omega) \cdot i_{d r} \cdot \eta .
$$

The inertia moment, reduced to the crank rotation axis, is determined by the dependence

$$
\begin{aligned}
& J_{d r}=J_{o} i_{d r}^{2}+m_{1}\left(\frac{\partial x_{1}}{\partial \varphi}\right)^{2}+m_{2}\left(\frac{\partial x_{2}}{\partial \varphi}\right)^{2}+m_{3}\left(\frac{\partial x_{3}}{\partial \varphi}\right)^{2}+l \cdot q\left[\left(\frac{\partial x_{s 4}}{\partial \varphi}\right)^{2}+\left(\frac{\partial y_{s 4}}{\partial \varphi}\right)^{2}\right]+J_{s 4}\left(\frac{\partial \beta_{1}}{\partial \varphi}\right)^{2}+ \\
& +l \cdot q\left[\left(\frac{\partial x_{s 5}}{\partial \varphi}\right)^{2}+\left(\frac{\partial y_{s 5}}{\partial \varphi}\right)^{2}\right]+J_{s 5}\left(\frac{\partial \beta_{2}}{\partial \varphi}\right)^{2}+l \cdot q\left[\left(\frac{\partial x_{s 6}}{\partial \varphi}\right)^{2}+\left(\frac{\partial y_{s 6}}{\partial \varphi}\right)^{2}\right]+J_{s 6}\left(\frac{\partial \beta_{3}}{\partial \varphi}\right)^{2},(9)
\end{aligned}
$$

where $J_{o}=J_{e m}+J_{c t h}+J_{\text {red }}=0,183+0,32+0,036=0,539 \mathrm{~kg} \cdot \mathrm{m}^{2}$ - inertia moment of the drive mechanism (electric motor, pin flexible coupling, reducer) relative to the crank rotation axis; $m_{1}=m_{2}=m_{3}=1000 \mathrm{~kg}$ - masses of the forming trolleys 1,2 and $3 ; J_{s 4}=J_{s 5}=J_{s 6}=\left(q \cdot l^{3}\right) / 12$ - proper inertia moment of connecting rods 4,5 and 6 with respect to their masses centers; $\frac{\partial x_{s 4}}{\partial \varphi}, \frac{\partial x_{s 5}}{\partial \varphi}$, $\frac{\partial x_{s 6}}{\partial \varphi}, \frac{\partial \beta_{1}}{\partial \varphi}, \frac{\partial \beta_{2}}{\partial \varphi}, \frac{\partial \beta_{3}}{\partial \varphi}$ - horizontal components of the first transfer functions for the masses centers of the connecting rods 4, 5 and 6 , and the first transfer functions of their angular arrangement relative to the horizontal line, which are determined as follows

$$
\begin{gathered}
\frac{\partial x_{s 4}}{\partial \varphi}=-r \cdot \sin \varphi \cdot\left(1+\frac{r}{2 \cdot l} \cdot \frac{\cos \varphi}{\sqrt{1-\left(r^{2} / l^{2}\right) \cdot \sin ^{2} \varphi}}\right), \\
\frac{\partial x_{S 5}}{\partial \varphi}=-r \cdot \sin (\varphi+\Delta \varphi) \cdot\left(1+\frac{r}{2 \cdot l} \cdot \frac{\cos (\varphi+\Delta \varphi)}{\sqrt{1-\left(r^{2} / l^{2}\right) \sin ^{2}(\varphi+\Delta \varphi)}}\right), \\
\frac{\partial x_{S 6}}{\partial \varphi}=-r \cdot \sin (\varphi+2 \cdot \Delta \varphi) \cdot\left(1+\frac{r}{2 \cdot l} \cdot \frac{\cos (\varphi+2 \cdot \Delta \varphi)}{\sqrt{1-\left(r^{2} / l^{2}\right) \cdot \sin ^{2}(\varphi+2 \cdot \Delta \varphi)}}\right), \\
\frac{\partial \beta_{1}}{\partial \varphi}=\frac{r}{l} \cdot \frac{\cos \varphi}{\sqrt{1-\left(r^{2} / l^{2}\right) \cdot \sin ^{2} \varphi}}, \frac{\partial \beta_{2}}{\partial \varphi}=\frac{r}{l} \cdot \frac{\cos (\varphi+\Delta \varphi)}{\sqrt{1-\left(r^{2} / l^{2}\right) \cdot \sin ^{2}(\varphi+\Delta \varphi)}}, \\
\frac{\partial \beta_{3}}{\partial \varphi}=\frac{r}{l} \cdot \frac{\cos (\varphi+2 \cdot \Delta \varphi)}{\sqrt{1-\left(r^{2} / l^{2}\right) \cdot \sin ^{2}(\varphi+2 \cdot \Delta \varphi)}} .
\end{gathered}
$$


On the basis of the above dependencies we construct a change graph of the inertia moment, reduced to the crank rotation axis, on the crank rotation angle for one cycle (Fig. 2 (b)).

The time, respondent to value $\omega_{i+1}$ angular velocity, can be determined by the dependence

$$
t_{i+1}=t_{i}+\frac{2 \cdot \Delta \varphi}{\omega_{i}+\omega_{i+1}},
$$

by means of which we obtain the crank angular acceleration

$$
\varepsilon_{i}=\frac{\omega_{i+1}-\omega_{i}}{t_{i+1}-t_{i}}
$$

where $t_{i}, t_{i+1}$ - motion time value in crank positions $i$ and $i+1$.

Having substitute, the obtained dependences into equation (4) for each settlement point, starting from the rest state $(i=0)$, we obtain a change graph of the crank angular velocity on the crank rotation angle (Fig. 3 (a)). Using dependence (12), we construct a change graph of the crank angular acceleration on the crank rotation angle (Fig. 3 (b)).

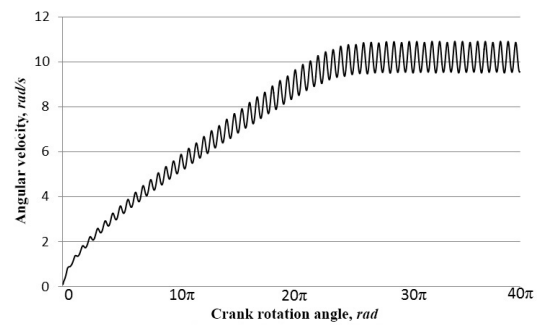

(a)

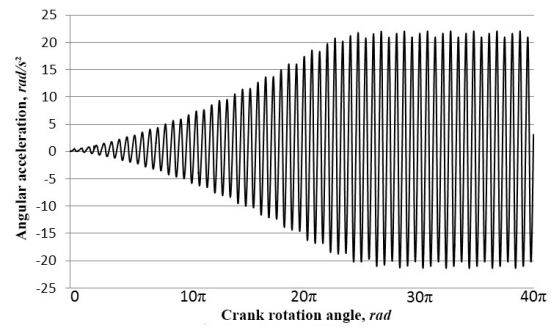

(b)

Fig. 3. Graphic dependencies of the crank angular velocity (a) and the crank angular acceleration (b) on the crank rotation angle

After analysis of graphic dependencies (Fig. 3), it can be seen that during of 13 crank rotations its angular velocity is constantly increase, and the angular acceleration is constantly increase its amplitude. After 13 crank rotations, the angular velocity and angular acceleration are change within certain limits (Fig. 4 ), that is the crank rotation reaches a steady motion mode. This means that the roller forming unit enters the steady motion mode for 13 full crank rotations from start-up moment.

After entering the steady motion mode, the crank rotates with a certain angular velocity (Fig. 4 (a)), which varies from $\omega_{\min }=9,714 \mathrm{rad} / \mathrm{s}$ to $\omega_{\max }=10,845 \mathrm{rad} / \mathrm{s}$. In this case, the average value of angular velocity is equal to $\omega_{\text {mean }}=10,263 \mathrm{rad} / \mathrm{s}$, and the motion non-uniformity factor is determined by the dependence [19]

$$
\delta=\frac{\omega_{\max }-\omega_{\min }}{\omega_{\text {mean }}}=\frac{10,845-9,714}{10,263}=0,11
$$




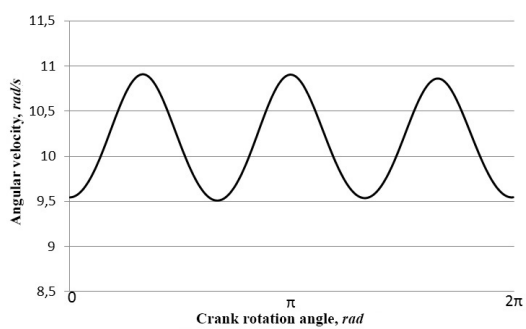

(a)

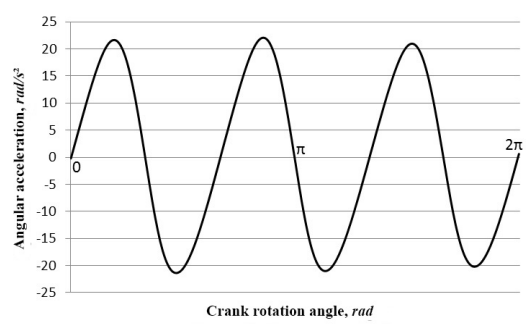

(b)

Fig. 4. Graphic dependencies of the crank angular velocity (a) and the crank angular acceleration (b) on the crank rotation angle during steady motion mode

The angular acceleration at a steady motion mode of the crank varies from $\varepsilon_{\text {min }}=-17,307 \mathrm{rad} / \mathrm{s}^{2}$ to $\varepsilon_{\max }=17,778 \mathrm{rad} / \mathrm{s}^{2}$ (Fig. $4, \mathrm{~b}$ ). In this case, the motion dynamism factor will have the look [19]

$$
\chi=\frac{\left|\varepsilon_{\max }\right|}{\omega_{\text {mean }}^{2}}=\frac{17,778}{10,263^{2}}=0,169 .
$$

For the total assessment of technological and dynamic properties of the roller forming unit, we use the extended factor of motion assessment [22]

$$
k_{p}=\frac{\left(\omega_{\max }-\omega_{\min }\right)^{2}}{\omega_{\text {mean }}^{2}}+\frac{\left|\varepsilon_{\max }\right|}{\omega_{\text {mean }}^{2}}=\frac{(10,845-9,714)^{2}}{10,263^{2}}+\frac{17,778}{10,263^{2}}=0,181 .
$$

The determined factor of motion non-uniformity, the motion dynamism factor and the extended factor of motion assessment are meet to the roller forming unit with energy-balanced drive in which the cranks displacement angle $\Delta \varphi=120^{\circ}$. Into dependencies to determine of the resistance forces moment and the inertia moment, whose reduced to the crank rotation axis, we substitute different values of the angle $\Delta \varphi$ from $\Delta \varphi=0^{\circ}$ to $\Delta \varphi=120^{\circ}$ with a step $10^{\circ}$, to set the impact of cranks displacement angle on the motion uniformity of the roller forming unit.

The graphic dependencies of crank angular velocity and crank angular acceleration on the crank rotation angle are constructed at these values of the resistance forces moment and the inertia reduced moment. After that, the motion non-uniformity factor, the motion dynamism factor and the extended factor of motion assessment are determined. The settlement results are shown in Table 1. The change graphs of the crank angular velocity (Fig. 5) and the crank angular acceleration (Fig. 6) during steady motion mode at different values of the crank displacement angle $\Delta \varphi$ are also resulted. 


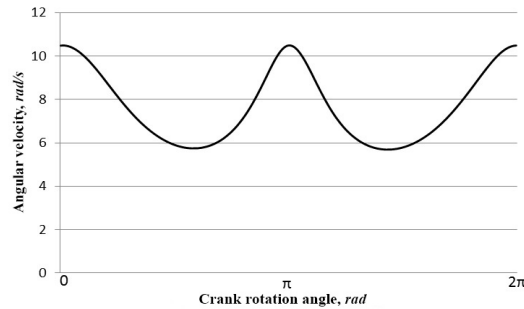

(a)

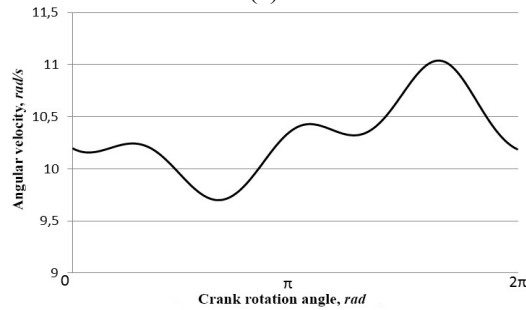

(c)

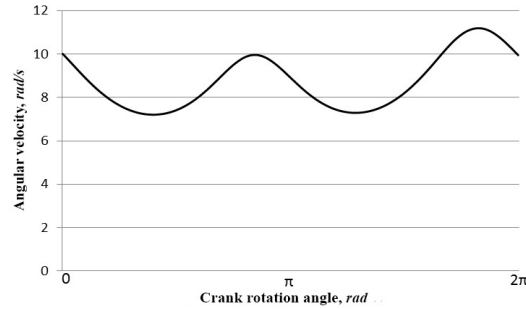

(b)

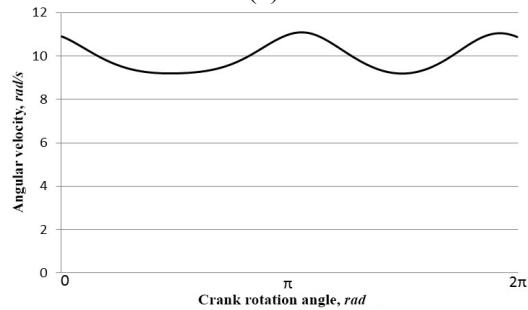

(d)

Fig. 5. Graphic dependencies of the crank angular velocity on the crank rotation angle during steady motion mode at different values of the crank displacement angle:

(a) $-\Delta \varphi=0^{\circ} ;$ (b) $-\Delta \varphi=30^{\circ} ;$ (c) $-\Delta \varphi=60^{\circ} ;$ (d) $-\Delta \varphi=90^{\circ}$

On the basis of Table 1 data, we construct graphic dependencies of the motion non-uniformity factor (Fig. 7 (a)), the motion dynamism factor (Fig. 7 (b)) and the extended factor of motion assessment (Fig. 7 (c)) from cranks displacement angle depending.

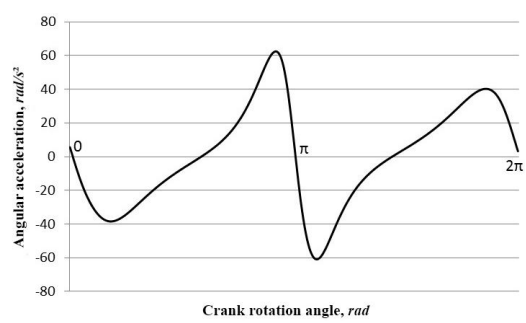

(a)

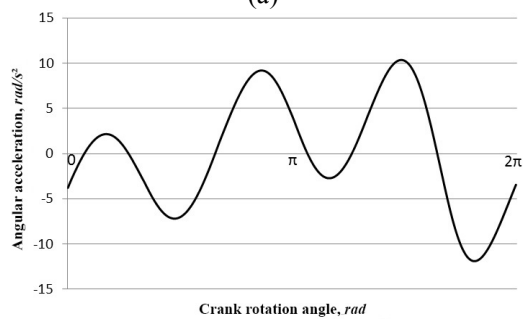

(c)

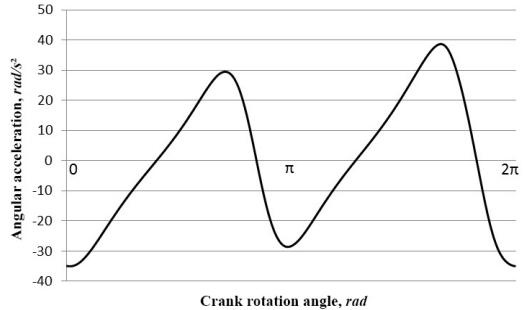

(b)

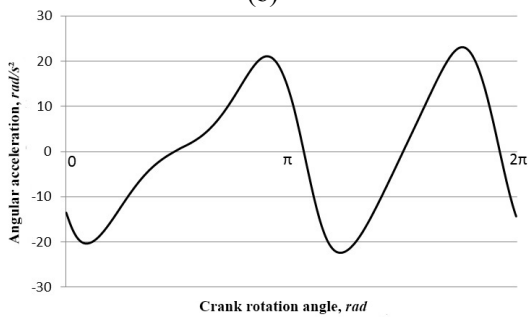

(d)

Fig. 6. Graphic dependencies of the crank angular acceleration on the crank rotation angle during steady motion mode at different values of the crank displacement angle:

(a) $-\Delta \varphi=0^{\circ} ;$ (b) $-\Delta \varphi=30^{\circ} ;$ (c) $-\Delta \varphi=60^{\circ} ;$ (d) $-\Delta \varphi=90^{\circ}$ 
Table 1

\begin{tabular}{|c|c|c|c|c|c|c|c|c|}
\hline$\Delta \varphi$, & $\begin{array}{c}\omega_{\min }, \\
\mathrm{rad} / \mathrm{s}\end{array}$ & $\begin{array}{c}\omega_{\max }, \\
\mathrm{rad} / \mathrm{s}\end{array}$ & $\begin{array}{c}\omega_{\text {mean }}, \\
\mathrm{rad} / \mathrm{s}\end{array}$ & $\delta$ & $\begin{array}{c}\varepsilon_{\min }, \\
\mathrm{rad} / \mathrm{s}^{2}\end{array}$ & $\begin{array}{c}\varepsilon_{\max }, \\
\mathrm{rad} / \mathrm{s}^{2}\end{array}$ & $\chi$ & $k_{p}$ \\
\hline 0 & 5,688 & 10,486 & 7,6767 & 0,625 & $-60,9412$ & 62,4776 & 1,060169 & 1,450804 \\
\hline 10 & 5,921 & 10,6648 & 7,68 & 0,6177 & $-56,1148$ & 57,6416 & 0,977268 & 1,358799 \\
\hline 20 & 6,3252 & 10,7094 & 8,0571 & 0,5441 & $-41,7004$ & 42,3337 & 0,652122 & 0,948211 \\
\hline 30 & 7,203 & 11,1871 & 8,7296 & 0,4564 & $-35,0305$ & 38,6718 & 0,507465 & 0,715756 \\
\hline 40 & 8,461 & 11,7789 & 9,6724 & 0,343 & $-34,4285$ & 33,5395 & 0,368002 & 0,485669 \\
\hline 50 & 9,5214 & 11,7132 & 10,2357 & 0,2141 & $-25,7271$ & 22,4492 & 0,245559 & 0,291412 \\
\hline 60 & 9,6998 & 11,0392 & 10,311 & 0,1299 & $-11,8928$ & 10,3499 & 0,111862 & 0,128736 \\
\hline 70 & 9,368 & 10,7795 & 10,2584 & 0,1376 & $-13,705$ & 15,5615 & 0,147874 & 0,166806 \\
\hline 80 & 9,1653 & 10,9716 & 10,1092 & 0,1787 & $-17,5584$ & 18,7243 & 0,18322 & 0,215146 \\
\hline 90 & 9,1906 & 11,0884 & 9,9874 & 0,19002 & $-22,3837$ & 23,0898 & 0,231481 & 0,267588 \\
\hline 100 & 9,0535 & 11,1918 & 10,0084 & 0,2136 & $-27,1379$ & 27,2824 & 0,272366 & 0,318013 \\
\hline 110 & 9,2219 & 11,1994 & 10,1349 & 0,1951 & $-27,4193$ & 26,8982 & 0,266942 & 0,305013 \\
\hline 120 & 9,5087 & 10,9078 & 10,1752 & 0,1375 & $-21,3797$ & 22,0726 & 0,21319 & 0,232097 \\
\hline
\end{tabular}

The analysis of settlement results (Table 1) and graphic dependencies (Fig. 7) shows that the motion non-uniformity factor takes the minimum value $\delta=0,1299$ when shift to crank angle $\Delta \varphi=60^{\circ}$, which is $5,8 \%$ less than at $\Delta \varphi=120^{\circ}$; the motion dynamism factor takes the minimum value $\chi=0,111862$ at $\Delta \varphi=60^{\circ}$, which is 1,906 less than at $\Delta \varphi=120^{\circ}$; the extended factor of motion assessment takes the minimum value $k_{p}=0,128736$ at the cranks displacement angle $\Delta \varphi=60^{\circ}$, which is 1,802 less than at $\Delta \varphi=120^{\circ}$.

\section{Conclusions}

As a result of researches, the change functions of the crank angular velocity and the crank angular acceleration for the roller forming unit with energybalanced drive are obtained, and the motion non-uniformity

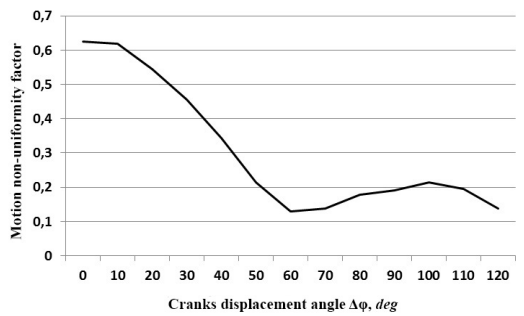

(a)

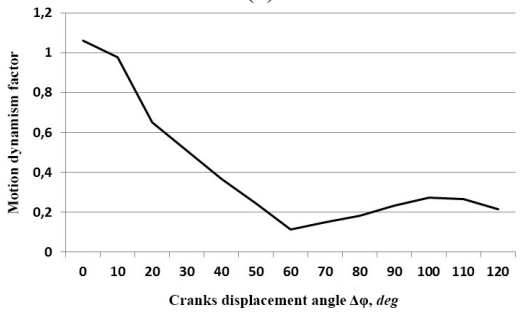

(b)

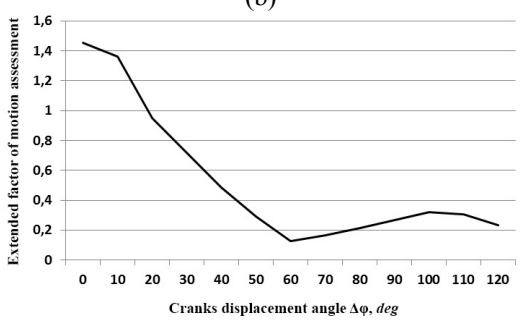

(c)

Fig. 7. Graphic dependencies of the motion nonuniformity factor (a), the motion dynamism factor (b) and the extended factor of motion assessment (c) on the crank displacement angle 
factor, the motion dynamism factor and the extended factor of motion assessment were calculated. The impact of the crank displacement angle on the motion uniformity of the roller forming unit is analyzed. It is established that the minimum values for the motion non-uniformity factor, the motion dynamism factor and the extended factor of motion assessment are observed at the values of cranks displacement angle $\Delta \varphi=120^{\circ}$. The work results may in the future are used to refine and improve the existing engineering methods for estimating the drive mechanisms of roller forming machines, both at design stages and in practical use.

\section{REFERENCES}

1. Harnets V. M. Prohresyvni betonoformuiuchi ahrehaty i kompleksy (Progressive concreteforming units and complexes). Kyiv: Budivelnyk, 1991. 144 p. [in Ukrainian].

2. Harnets V. M., Zaichenko S. V., Chovniuk Yu. V., Shalenko V. O., Prykhodko Ya. S. Betonoformuvalni ahrehaty. Konstruktyvno-funktsionalni skhemy, pryntsyp dii, osnovy teorii: Monohrafiia (Concrete-forming units. Structural and functional schemes, operation principle, theory basics: Monograph). Kyiv: Interservis, 2015. 238 p. [in Ukrainian].

3. Kuzin V. N. Tehnologija rolikovogo formovanija ploskih izdelij iz melkozernistyh betonov (Roller forming technology of flat products from fine-grained concrete: Extended abstract of candidate's thesis). Moscow, 1981.20 p. [in Russian].

4. Rjushin V. T. Issledovanie rabochego processa $\mathrm{i}$ razrabotka metodiki rascheta mashin rolikovogo formovanija betonnyh smesej (Working process research and methodology development of calculating machines for concrete mixtures roller forming: Extended abstract of candidate's thesis). Kyiv, 1986. 20 p. [in Russian].

5. Loveikin V.S., Pochka K. I. Dynamichnyi analiz rolykovoi formovochnoi ustanovky z rekuperatsiinym pryvodom (Dynamic analysis of roller forming unit with recuperative drive). Dynamika, mitsnist i nadiinist silskohospodarskykh mashyn: materialy pershoi Mizhnarodnoi naukovo-tekhnichnoi konferentsii (Dynamics, Strength and Reliability of Agricultural Machinery: Proceedings of the 1st International Scientific and Technical Conference (DSR AM-I). Ternopil, 2004. P. 507-514 (in Ukrainian).

6. Nazarenko I. I., Smirnov V. M., Pelevin L. Ye., Fomin A. V., Sviderskyi A. T., Kosteniuk O. O., Ruchynskyi M. M., Diedov O. P., Harkavenko O. M., Martyniuk I. Yu. Osnovy teorii rukhu zemleryinykh i uschilniuvalnykh mashyn budindustrii $\mathrm{z}$ kerovanymy u chasi optymalnymy parametramy: Monohrafiia (Motion theory fundamentals of earthmoving and compaction machines for building industry with time-controlled optimal parameters: Monograph). Kyiv: MP Lesia, 2013. 188 p. (in Ukrainian).

7. Zaichenko S., Shalenko V., Shevchuk N., Vapnichna V. Development of a geomechanic complex for geotechnical monitoring contour mine groove. Eastern-European Journal of Enterprise Technologies. 2017. Vol. 3/9 (87). P. 19-25. DOI: 10.155/1729-4061.2017.102067.

8. Harnets V. M., Chovniuk Yu. V., Zaichenko S. V., Shalenko V. O., Prykhodko Ya. S. Teoriia i praktyka stvorennia betonoformuvalnykh ahrehativ (BFA) (Theory and practice of creating concrete-forming units). Hirnychi, budivelni, dorozhni ta melioratyvni mashyny. 2014. Issue 83. P. 49-54 (in Ukrainian).

9. Harnets V. M., Zaichenko S. V., Prykhodko Ya. S., Shalenko V. O. Rozrobka naukovopraktychnykh rekomendatsii po stvorenniu betonoformuiuchykh ahrehativ (BFA) (Development of scientific and practical recommendations for the creation of concreteforming). Hirnychi, budivelni, dorozhni ta melioratyvni mashyny. 2012. Issue 79. P. 46-52 (in Ukrainian).

10. Zaichenko S. V., Shevchuk S. P., Harnets V. M. Enerhetychnyi analiz protsesu rolykovoho uschilnennia (Energy analysis of the roller compaction process). Enerhetyka: Ekonomika, tekhnolohiia, ekolohiia. 2012. Vol. 1 (30). P. 77-83 (in Ukrainian).

11. Zaichenko S. V., Shevchuk S. P., Harnets V. M. Tryvymirne modeliuvannia protsesu rolykovoho uschilnennia stovburnoho kriplennia (Three-dimensional modeling of roller 
compaction process of the trunk). Hirnychi, budivelni, dorozhni ta melioratyvni mashyny. 2012. Issue 79. P. 40-45 (in Ukrainian).

12. Prykhodko Ya. S., Harnets V. M. Vzaiemouzghodzhenist roboty mekhanizmiv pry rolykoekstruziinomu formuvanni bahatopustotnykh vyrobiv (Mutual coherence of mechanisms in roller-extrusion forming of multi-hollow products). Haluzeve mashynobuduvannia, budivnytstvo. 2012. Vol. 1 (31). P. 305-310. (in Ukrainian).

13. Loveikin V.S., Pochka K. I., Romasevych Yu. O., Pochka O. B. Dynamichnyi analiz rolykovoi formuvalnoi ustanovky z kryvoshypno-shatunnym pryvidnym mekhanizmom (Dynamic analysis of roller forming unit with crank drive mechanism). Opir materialiv $i$ teoriia sporud. 2019. Issue 102. P. 91-108. DOI: 10.32347/2410-2547.2019.102.91-108 (in Ukrainian).

14. Loveikin V. S., Pochka K. I., Prystailo M. O., Pochka O. B. Dynamichne zrivnovazhennia pryvidnoho mekhanizmu rolykovoi formuvalnoi ustanovky z enerhetychno vrivnovazhenym pryvodom (Drive mechanism dynamic balancing of roller forming unit with energy-balanced drive). Opir materialiv i teoriia sporud. 2019. Issue 103. P. 112-130. DOI: 10.32347/24102547.2019.103.112-130 (in Ukrainian).

15. Loveikin V.S., Pochka K. I. Sintez kulachkovogo privodnogo mehanizma rolikovoj formovochnoj ustanovki s kombinirovannym rezhimom dvizhenija po uskoreniju tret'ego porjadka (Synthesis of a cam drive mechanism for roller forming unit with combined thirdorder acceleration mode). Nauka i tehnika. Minsk, 2017. Vol. 16 (3). P. 206-214. DOI: 10.21122/2227-1031-2017-16-3-206-214 (in Russian).

16. Loveikin V. S., Pochka K. I. Analiz nerivnomirnosti rukhu rolykovoi formuvalnoi ustanovky z enerhetychno vrivnovazhenym pryvodom (Motion non-uniformity analysis of roller forming unit with energy-balanced drive). Vibratsii v tekhnitsi ta tekhnolohiiakh. 2010. Vol. 4 (60). P. 20-29 (in Ukrainian).

17. Loveikin V.S., Pochka K. I. Obgruntuvannia parametriv enerhetychno vrivnovazhenoho pryvodu rolykovoi formuvalnoi ustanovky (Parameters substantiation of energy-balanced drive for roller forming unit). Tekhnika budivnytstva. 2014. Issue 32. P. $25-32$ (in Ukrainian).

18. Pat. 50032 U Ukraine, IPC B28B 13/00. Ustanovka dlia formuvannia vyrobiv z betonnykh sumishei (Forming unit for products from concrete mixtures) / Loveikin V. S., Pochka K. I. Publ. 25.05.2010 (in Ukrainian).

19. Artobolevskij I. I. Teorija mehanizmov i mashin (Mechanisms and machines theory). Moscow, 1975. 640 p. (in Russian).

20. Orlov I. N. Jelektrotehnicheskij spravochnik (Electrotechnical handbook)/ (Vol. 1-3). Vol. 2. Jelektrotehnicheskie izdelija i ustrojstva (Electrical products and devices). Moscow, 1986. 712 p. (in Russian).

21. Shejnblit A. E. Kursovoe proektirovanie detalej mashin (Course design of machine parts). Moscow, 1991. 432 p. (in Russian).

22. Loveikin V. S. Ocenka dvizhenija mehanizmov i mashin (Motion assessment of mechanisms and machines). Podyemno-transportnoe oborudovanie. Kyiv: Tehnika, 1989. P. 16-18 (in Russian).

Стаття надійшла до редакиії 24.12.2020

\section{Ловейкін В. С., Почка К. І., Пристайло М. О., Балака М. М., Почка О. Б. \\ ВПЛИВ КУТА ЗМІЩЕННЯ КРИВОШИПІВ НА НЕРІВНОМІРНІСТЬ РУХУ

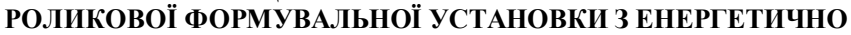 ВРІВНОВАЖЕНИМ ПРИВОДОМ}

Для роликової формувальної установки 3 енергетично врівноваженим привідним механізмом для трьох формувальних візків визначено вплив кута зміщення кривошипів на нерівномірність руху. При цьому вказана установка представлена динамічною моделлю 3 одним ступенем вільності, де за узагальнену координату прийнято кутову координату повороту кривошипу. Для такої моделі записано диференціальне рівняння руху, для розв'язку якого було використано чисельний метод. При розв'язку диференціального рівняння руху було визначено зведений момент інерції всієї установки, зведений до осі повороту кривошипа момент сил опору переміщенню формувальних візків при формуванні виробів 3 будівельних сумішей, розраховано номінальну розрахункову потужність 
привідного двигуна. За розрахованими даними вибрано асинхронний електродвигун 3 короткозамкненим ротором, для якого за формулою Клосса побудовано механічну характеристику. Розв'язавши диференціальне рівняння руху 3 усіма визначеними характеристиками, отримано функцію зміни кутової швидкості кривошипу з моменту пуску і при усталеному режимі руху. Після цього розраховано час, що відповідає значенню кутової швидкості, та отримано функцію зміни кутового прискорення кривошипу з моменту пуску і при усталеному режимі руху. Нерівномірність руху установки на усталеному режимі руху оцінена коефіцієнтом нерівномірності руху, коефіцієнтом динамічності руху та узагальненим коефіцієнтом оцінки руху. Отримані результати можуть бути у подальшому використані для уточнення та вдосконалення існуючих інженерних методів розрахунку привідних механізмів машин роликового формування як на стадіях проектування, так i y режимах реальної експлуатації.

Ключові слова: роликова формувальна установка, привідний механізм, зміщення, кутова швидкість, прискорення, нерівномірність.

Loveikin V. S., Pochka K. I., Prystailo M. O., Balaka M. M., Pochka O. B.

IMPACT OF CRANKS DISPLACEMENT ANGLE ON THE MOTION NONUNIFORMITY OF ROLLER FORMING UNIT WITH ENERGY-BALANCED DRIVE

The impact of the cranks displacement angle on the motion non-uniformity is determined for three forming trolleys of a roller forming unit with an energy-balanced drive mechanism. At the same time, the specified unit is presented by a dynamic model with one freedom degree, where the extended coordinate is taken as the angular coordinate of the crank rotation. For such a model, a differential equation of motion is written, for solved which a numerical method was used. The inertia reduced moment of the whole unit, and the resistance forces moment, reduced to the crank rotation axis, to move of forming trolleys during the formation of products from building mixtures are determined, and also the nominal rated power of the electric motor was calculated, when solved a differential equation of motion. According to these data, asynchronous electric motor with a short-circuited rotor was chosen, for which a mechanical characteristic is constructed by the Kloss formula. Having solved the differential equation of motion with all defined characteristics, we obtain the change function of the crank angular velocity from start-up moment and during steady motion mode. After that, we calculated the time corresponding to the angular velocity value, and obtained the change function of the crank angular acceleration from start-up moment and during steady motion mode. The motion non-uniformity of the roller forming unit has been determined by the motion non-uniformity factor, the motion dynamism factor and the extended factor of motion assessment during steady motion mode. The impact of drive cranks displacement angle on the motion non-uniformity has been traced, as a result, the specified factors have the minimum values at cranks displacement on the angle $\Delta \varphi=60^{\circ}$. The results may in the future are used to refine and improve the existing engineering methods for estimating the drive mechanisms of roller forming machines, both at design stages and in practical use.

Keywords: roller forming unit, drive mechanism, displacement, angular velocity, acceleration, non-uniformity.

\section{Ловейкин В. С., Почка К. И., Пристайло Н. А., Балака М. Н., Почка О. Б. \\ ВЛИЯНИЕ УГЛА СМЕЩЕНИЯ КРИВОШИПОВ НА НЕРАВНОМЕРНОСТЬ ДВИЖЕНИЯ РОЛИКОВОЙ ФОРМОВОЧНОЙ УСТАНОВКИ С ЭНЕРГЕТИЧЕСКИ УРАВНОВЕШЕННЫМ ПРИВОДОМ}

Для роликовой формовочной установки с энергетически уравновешенным приводным механизмом для трёх формовочных тележек определено влияние угла смещения кривошипов на неравномерность движения. При этом указанная установка представлена динамической моделью с одной степенью свободы, где в качестве обобщённой координаты принято угловую координату поворота кривошипа. Для такой модели записано дифференциальное уравнение движения, для решения которого использован численный метод. При решении дифференциального уравнения движения определены приведенный момент инерции всей установки, приведенный к оси вращения кривошипа момент сил сопротивления перемещению формовочных тележек при формовании изделий из строительных смесей, рассчитана номинальная расчётная мощность приводного двигателя. По рассчитанным данным выбран асинхронный электродвигатель с короткозамкнутым 
ротором, для которого по формуле Клосса построена механическая характеристика. Решив дифференциальное уравнение движения со всеми определёнными характеристиками, получена функция изменения угловой скорости кривошипа с момента пуска и при установившемся режиме движения. После этого рассчитано время, соответствующее значению угловой скорости, и получена функция изменения углового ускорения кривошипа с момента пуска и при установившемся режиме движения. Неравномерность движения установки на установившемся режиме движения оценена коэффициентом неравномерности движения, коэффициентом динамичности движения и обобщённым коэффициентом оценки движения. Отслежено влияние угла смещения кривошипов привода на неравномерность движения, в результате чего установлено, что указанные коэффициенты имеют минимальные значения при смещении кривошипов на угол $\Delta \varphi=60^{\circ}$. Полученные результаты могут быть в дальнейшем использованы для уточнения и усовершенствования существующих инженерных методов расчёта приводных механизмов машин роликового формования как на стадиях проектирования, так и в режимах реальной эксплуатации.

Ключевые слова: роликовая формовочная установка, приводной механизм, смещение, угловая скорость, ускорение, неравномерность.

\section{УДК 693.546}

Ловейкін В. С., Почка К. І., Пристайло М. О., Балака М. М., Почка О. Б. Вплив кута зміщення кривошипів на нерівномірність руху роликової формувальної установки 3 енергетично врівноваженим приводом // Опір матеріалів і теорія споруд: наук.-техн. зб. 2021. - Вип. 106. - С. 141-155.

Дослілжується вплив кута зміщчення кривошипів на нерівномірність руху роликової формувальної установки з енергетично врівноваженим приводом.

Табл. 1. Іл. 7. Бібліогр. 22.

\section{UDC 693.546}

Loveikin V.S., Pochka K. I., Prystailo M. O., Balaka M. M., Pochka O. B. Impact of cranks displacement angle on the motion non-uniformity of roller forming unit with energybalanced drive // Strength of Materials and Theory of Structure: Scientific-and-technical collected articles. - 2021. - Issue 106. - P. 141-155.

The influence of the crank displacement angle on the non-uniformity of the movement of the roller forming unit with the energy-balanced drive is investigated.

Table 1. Fig. 7. Ref. 22.

\section{УДК 693.546}

Ловейкин В. С., Почка К. И., Пристайло Н. А., Балака М.Н., Почка О.Б. Влияние угла смещения кривошипов на неравномерность движения роликовой формовочной установки с энергетически уравновешенным приводом // Сопротивление материалов и теория сооружений: науч.-техн. сб. - 2021. - Вып. 106. - С. 141-155.

Исследуется влияние угла смещения кривошипа на неравномерность движения роликов формовочной установки с энергетично уравновешенный приводом.

Табл. 1. Ил. 7. Библиогр. 22. 
Автор (вчена ступень, вчене звання, посада): доктор технічних наук, професор, завідувач кафедри конструювання машин $і$ обладнання Національного університету біоресурсів $i$ природокористування Украӥни ЛОВЕЙКІН Вячеслав Сергійович

Адреса робоча: 03041, Украӥна, м. Київ, вул. Героїв Оборони, 12, навчальний корпус № 11, Національний університет біоресурсів $i$ природокористування України, кафедра конструювання машин і обладнання, ЛОВЕЙКІНУ Вячеславу Сергійовичу

Робочий тел.: +38(044) 527-87-34

Мобільний тел.: +38(097) 349-14-53

E-mail: lovvs@ukr.net

ORCID ID: https://orcid.org/0000-0003-4259-3900

Автор (вчена ступень, вчене звання, посада): доктор технічних наук, доцент, завідувач кафедри професійної освіти КНУБА ПОЧКА Костянтин Іванович

Адреса робоча: 03037, Украӥна, м. Київ, Повітрофлотський проспект 31, Київський національний університет будівництва і архітектури, кафедра професійної освіти, ПОЧЦІ Костянтину Івановичу

Робочий тел.: +38(044) 248-69-25

Мобільний тел.: +38(097) 212-86-29

E-mail: shanovniy@ukr.net

ORCID ID: https://orcid.org/0000-0002-0355-002X

Автор (вчена ступень, вчене звання, посада): кандидат технічних наук, доцент, доцент кафедри будівельних машин КНУБА ПРИСТАЙЛО Микола Олексійович

Адреса робоча: 03037, Украӥна, м. Київ, Повітрофлотський проспект 31, Київський національний університет будівництва $і$ архітектури, кафедра будівельних машин, ПРИСТАЙЛУ Миколі Олексійовичу

Мобільний тел.: +38(097) 495-07-50

E-mail: pristaylo na@ukr.net

ORCID ID: https://orcid.org/0000-0003-3151-4680

Автор (вчена ступень, вчене звання, посада): кандидат технічних наук, дочент кафедри будівельних машин КНУБА БАЛАКА Максим Миколайович

Адреса робоча: 03037, Украӥна, м. Київ, Повітрофлотський проспект 31, Київський національний університет будівництва $i$ архітектури, кафедра будівельних машин, БАЛАЦІ Максиму Миколайовичу

Мобільний тел.: +38(067) 995-53-89

E-mail: balaka.mm@knuba.edu.ua

ORCID ID: https://orcid.org/0000-0003-4142-9703

Автор (вчена ступень, вчене звання, посада): асистент кафедри теплогазопостачання $i$ вентиляції КНУБА ПОЧКА Ольга Богданівна

Адреса робоча: 03037, Украӥна, м. Київ, Повітрофлотський проспект 31, Київський національний університет будівництва $і$ архітектури, кафедра теплогазопостачання $i$ вентиляиії, ПОЧЦІ Ользі Богданівні

Мобільний тел.: +38(097) 196-92-04;

E-mail: zasedkoolga@ukr.net

ORCID ID: https://orcid.org/0000-0001-5701-978X 